\title{
Effect of Processing Methods on the Physicochemical, Mineral and Carotene Content of Orange Fleshed Sweet Potato (OFSP)
}

\author{
J. Eke-Ejiofor ${ }^{1} \&$ B. U. Onyeso ${ }^{1}$ \\ ${ }^{1}$ Department of Food Science and Technology, Rivers State University, Port Harcourt, Nigeria \\ Correspondence: J. Eke-Ejiofor, Department of Food Science and Technology, Rivers State University, Port \\ Harcourt, Nigeria. Tel: 234-703-311-7436. E-mail: joyekee@yahoo.co.uk
}

Received: March 4, 2019

Accepted: March 20, 2019 Online Published: April 5, 2019

doi:10.5539/jfr.v8n3p50

URL: https://doi.org/10.5539/jfr.v8n3p50

\begin{abstract}
The effect of processing methods on the physiochemical, mineral, vitamin $\mathrm{C}$ and carotenoid content of orange fleshed sweet potatoes were investigated. The processing methods used were boiling, steaming, roasting, frying and microwaving. The result of the proximate composition showed that the roasted orange fleshed sweet potatoes (OFSP) had the highest ash content ranging from 0.32-0.99\%, crude protein 0.96-3.12\%, crude fiber $0.50-3.40 \%$ and carbohydrate content $13.98-40.10 \%$ with a decrease in the moisture content from $83.10 \%$ $49.25 \%$. Fat content of the fried OFSP ranging from 0.96-6.01\% was higher than the other samples. Steaming method enhanced the vitamin C content of the OFSP when compared to other processing method, while carotenoid losses were higher after frying $2.59 \mathrm{mg} / \mathrm{g}$, than after microwaving $3-91 \%$, roasting $4.73 \mathrm{mg} / \mathrm{g}$, boiling $4.60 \mathrm{mg} / \mathrm{g}$ and steaming $2.68 \mathrm{mg} / \mathrm{g}$. Mineral analysis showed that the boiled orange flesh sweet potatoes (OFSP) had zinc, copper and magnesium content higher than the other heat treated samples with $6.21 \mathrm{mg} / \mathrm{g}$, $4,164 \mathrm{mg} / 100 \mathrm{~g}$ and $479.88 \mathrm{mg} / 100 \mathrm{~g}$ respectively. Sensory analysis results showed that there were no significant $(p<0.05)$ differences in the sensory scores of the orange-fleshed sweet potatoes. The study therefore showed that roasting and frying made available more protein, fat, ash and carbohydrate content, while boiling made available more minerals.
\end{abstract}

Keyword: orange flesh, sweet potatoes, processing, chemical, mineral. carotenoid

\section{Introduction}

Sweet potato (Ipomoea batatas) is a dicotyledonous starch, sweet tasting, and tuberous vegetable (John, 1998).It is a very important crop in the developing world and the seventh most important food crop in the world and fourth in tropical countries. They are also a main food crop of the tropical and subtropical areas and therefore can provide a nutritional advantage to the people of rural and urban regions by enhancing their production and increasing consumption (Woolfe, 2008).

Depending on the flesh color, sweet potatoes are rich in $\beta$-carotene, anthocyanin, total phenolic, dietary fiber, ascorbic acid, folic acid and minerals (Woolfe, 1992). Orange fleshed sweet potatoes (OFSP) are bred as a tool for the global fight against vitamin A deficiency in areas that lack vitamin A rich food materials (Degras, 2003). On dry matter basis, the non-carbohydrate macronutrient composition of the edible tuberous roots includes 1.4-8.6\% protein, 3.4-5.9\%, crude fibre, 0.3-1.9\% lipid and 1.5-6.3\% ash (Degras, 2003). They are good source of Vitamin A, Vitamin C, B-vitamins, potassium and copper (FAO, 2007). The pro-vitamin A $\beta$-carotene pigment is known to be responsible for the yellow to orange coloration of the flesh of tuberous roots of sweet potato varieties (Rodriguez-Amaya and Kimura, 2004). The orange fleshed sweet potato is a seasonal crop, perishable and cannot be stored for long period of time unless preserved in some way.

Cooking could make food palatable, digestible and microbiologically safe, with many chemical, physical and sensory changes occurring during cooking which has a great influence on the final organoleptic properties as well as the nutritional value of the cooked food including texture, color and aroma development (Erdman et al., 1994). The Orange-fleshed sweet potato passes through different processing methods before consumption such as blanching, cooking, frying and steaming which may result in nutrient loss as it is difficult to assess the nutritional value of the final product in the form in which potato is consumed. Cooking has been reported to either be beneficial or detrimental to the nutrient content of food (Chukwuet al., 2010), as it helps to improve nutrient bioavailability, destroy toxins, microbes and anti-nutritional factors in food (Erdman et al., 1994). There is 
little or no information on the effect of different cooking methods on nutrient retention of orange fleshed sweet potatoes. Therefore proper attention must be taken to establish an appropriate method that would best retain the nutrient content of food, especially orange fleshed sweet potato as food processing techniques are possible means of reducing or increasing nutrient levels. Knowledge on how the cooking methods affect the level of nutrient content could help establish the best cooking method that maintain the integrity of the components.

Therefore the objective of this work is to evaluate the effect of different cooking methods on the physicochemical, vitamin $\mathrm{C}$, carotene content and sensory properties of orange-fleshed sweet potato.

\section{Materials and Methods}

\subsection{Materials}

\subsubsection{Sample Preparation}

The orange fleshed sweet potato (OFSP) (Ipomoea batatasL) variety used for this study was harvested after three (3) months of planting from the Rukpokwu farm site of the Nigerian Stored Products Research Institute (NSPRI), Mile 4, Port Harcourt Rivers State, Nigeria. After harvest, good and healthy tubers were selected and $1.5 \mathrm{~kg}$ weight each was used for the different treatments.

\subsection{Methods}

\subsubsection{Oven-Roasting $\left(130^{\circ} \mathrm{C}\right.$ for $\left.12 \mathrm{~min}\right)$}

$1.5 \mathrm{~kg}$ samples of sweet potato were washed with clean water to remove dirt and other foreign materials. They were peeled using a knife, cut into cubes of about $1.5 \mathrm{~cm}$, washed using distilled water and placed in a pre-heated oven at $130^{\circ} \mathrm{C}$ for baking until ready to eat (12minutes). Samples were left to cool at room temperature and then milled. The samples were stored until required for further analysis.

\subsubsection{Frying}

Freshly harvested $1.5 \mathrm{~kg}$ weight of orange-fleshed sweet potato was peeled, sliced using knife to about $1.5 \mathrm{~cm}$ thickness and washed using distilled water. Frying was carried out in a frying pan having a capacity of $2 \mathrm{~L}$ oil for the frying of 200 gram of potatoes at a given time, which is 1:20 (w/v). The potato strips were fried in vegetable oil at about $120^{\circ} \mathrm{C}$ for $5 \mathrm{~min}$. Fried samples were allowed to cool at room temperature, mashed using a mortar and stored for further analysis.

\subsubsection{Boiling}

Freshly harvested $1.5 \mathrm{~kg}$ Orange-fleshed sweet potato were peeled, washed with distilled water, sliced to $1.5 \mathrm{~cm}$ thick and boiled at $100^{\circ} \mathrm{C}$ in clean water for about $15 \mathrm{~min}$ until tender, drained and cooled at room temperature. Mashed and stored for analysis.

\subsubsection{Microwave Cooking}

Orange fleshed sweet potato varieties $(1.5 \mathrm{~kg})$ were sliced to about $1.5 \mathrm{~cm}$ thickness. The sliced pieces were cooked in a microwave oven (Samsung model) for 5minutes at $600 \mathrm{~W}$ power. The samples were left to cool, mashed and stored for analysis.

\subsubsection{Steaming (Moist heat)}

$1.5 \mathrm{~kg}$ Orange fleshed sweet potato varieties were sliced to about $1.5 \mathrm{~cm}$ thickness. The sliced pieces were steamed in a steam pot at $100^{\circ} \mathrm{C}$ for $10 \mathrm{~min}$. The samples were left to cool, mashed and stored for further analysis. 


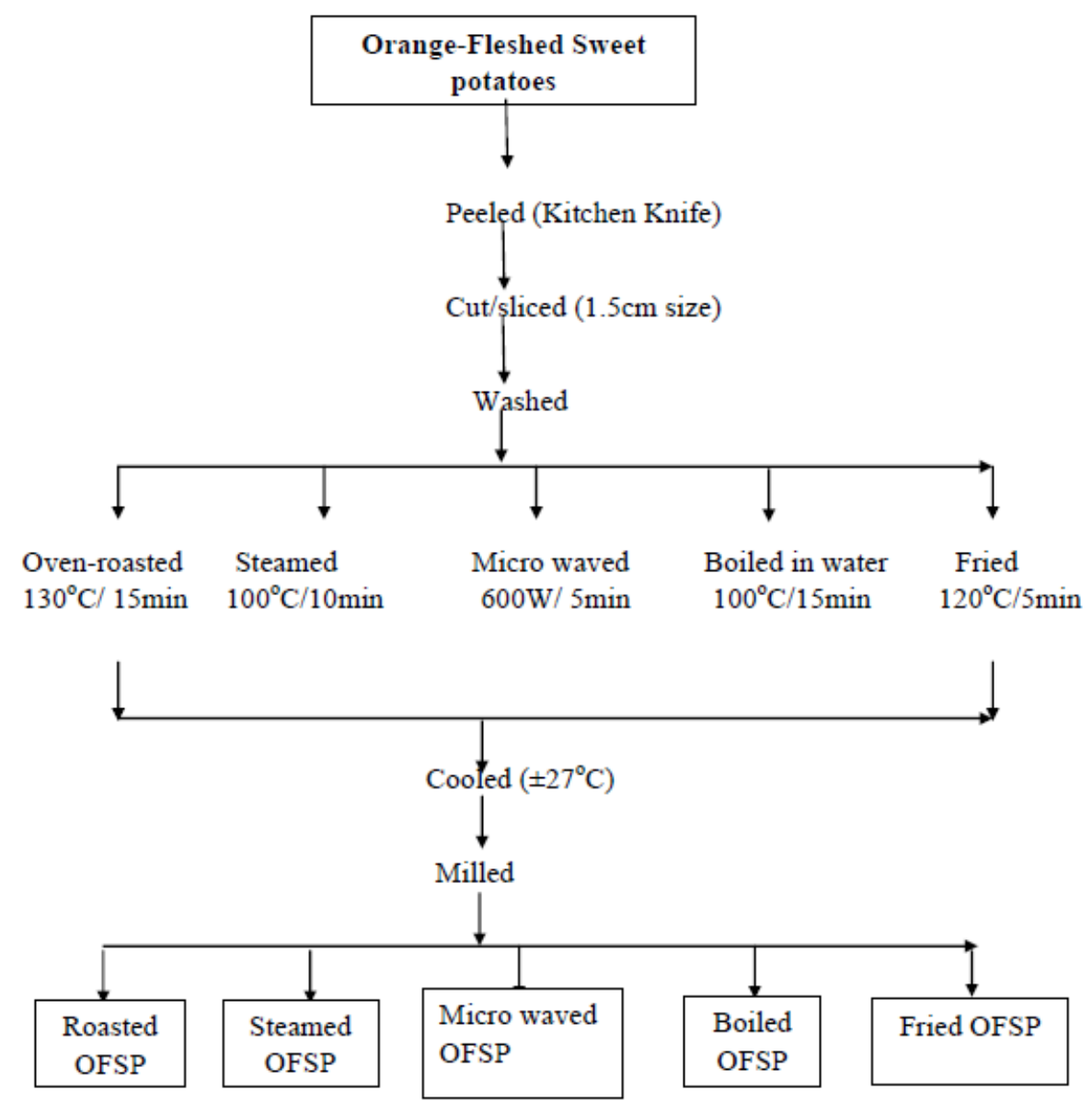

Figure 1. Flow chart for the processing of Orange-fleshed sweet potatoes using different processing method

\subsection{Sensory Analysis}

The sensory attributes of the heat processed orange fleshed sweet potatoes was done using simple nine point hedonic tests as described by Larmond (1991). This was done using a 20-member panellist comprising of students of the Department of Food Science and Technology, Rivers State University, who were used to consuming potatoes and where neither sick nor allergic to potatoes as at the time of the sensory testing. Scale used was 1 and 9 representing dislike extremely and like extremely respectively. The attributes evaluated include color, taste, texture, crispness and general acceptability.

\subsubsection{Proximate Analysis}

The moisture, ash, fat, protein, crude fibre and carbohydrate content were determined according to a procedure described by (AOAC, 2012), while total carotenoid was determined by the method of Harbone (1973)

\subsubsection{Mineral Determination}

The Mineral content of the samples was determined using the wet method as described by Onwuka (2005). Calcium, iron, zinc, potassium and magnesium element content was determined by atomic absorption spectrophotometer.

\subsubsection{Statistical Analysis}

Analyses were done in triplicate. Mean scores were analyzed statistically using analysis of variance and least significant difference (LSD) testwhich was defined at ( $\mathrm{p}<0.05)$ (Ihekoronye and Ngoddy, 1985).

\section{Results and Discussion}

\subsection{Proximate Composition of Orange-Fleshed Sweet Potato (OFSP) Samples Cooked with Different Methods}

Table 1 shows the proximate composition of orange-fleshed sweet potatoes (OFSP) from different cooking 
methods. Moisture content ranged from 49.25-83.10\% with boiled sample recording the highest and roasted sample the lowest. Moisture result revealed that there was a significant $(\mathrm{p}<0.05)$ difference in moisture content with the boiled sample having the highest. This is expected as the boiling process provided for the starch granules in potato to imbibe and retain more water. This high moisture content reduced their shelf life and storability. Moisture content is a key to determining when a food substance is safe to be packaged. Robert et al., (2017) also observed reduced moisture for roasted ripe plantain samples from $22.70-14.42 \%$ while Thomas et al.(2017) reported increase in moisture content from $66.79-69.50 \%$ for boiled yellow yam and reduced moisture for roasted yam samples $(57.85 \%)$. Roasting has been showed to reduce the moisture content of food materials than other thermal processing methods, owing to the dry technique where the food samples are heat treated without immersing in water liquid. It has been known that dry heat dehydrates foods causing water loss while the increase in moisture of steamed sample was due to the moist heat employed in the process.

Ash content of the OFSP ranged from $0.32-0.99 \%$ with roasted sample recording the highest, while fried and boiled OFSP samples had the lowest. There was also a significant $(\mathrm{p}<0.05)$ increase in the ash content of heat processed OFSP from $0.63 \%$ in the raw sample to $0.99 \%$ for roasted sample, $0.71 \%$ for steamed sample and $0.85 \%$ for micro waved sample, while ash decreased significantly $(\mathrm{p}<0.05)$ for boiled and fried OFSP samples respectively. Ash content of a food gives an indication of the mineral composition of the food sample (Genah et al. 2012). Water losses occurring during roasting may have resulted in higher ash content in roasted and fried plantain (Thomas et al., 2017) which was also applicable in the present study. The lower ash contents obtained for the boiled OFSP sample may be due to loss of minerals into the cooking water by leaching. To support this finding, previous work by Robert et al., (2017) showed that there was an increase in the ash content of yellow yam after roasting (0.63-1.42\%) while a decrease was observed by Thomas et al. (2017) for boiled plantain (3.31-3.14\%).

Fat content of the OFSP samples ranged from $0.96-6.01 \%$ with fried sample recording the highest and steamed sample the lowest. There was also a significant $(\mathrm{p}<0.05)$ increase in the fat content from $1.49 \%$ in the raw sample to $6.01 \%$ for fried sample and $3.15 \%$ for roasted sample, while a decrease in fat content was observed for boiled $(0.97 \%)$, micro waved $(1.42 \%)$ and steamed $(0.96 \%)$ respectively. The fat in the boiled, micro waved and steamed samples may have melted as a result of the high heat applied thus causing a reduction in the fat content (Tsado et al., 2015). The low fat content of the roasted samples would enhance the storage life of the product. This is in agreement with the findings of Thomas et al., (2017) who reported that low fat content resulting from roasting, lowered chances of rancid flavor development. Previous work by Robert et al., (2017) shows that there was an increase in the fat content of OFSP after frying $(0.27-7.12 \%)$ and for roasting $(0.46 \%)$ with a decrease in boiled yellow yam $(0.27 \%)$. Thomas et al., (2017) also reported $0.14-15.06 \%$ for fried ripe plantain. The high fat content of the fried OFSP sample may be due to oil absorption of the sample during the frying process on the food after water is partially lost by evaporation (Saguy and Dana, 2003).

Protein content of the OFSP samples treated with different heat processing ranged from $0.91-3.12 \%$ with the roasted sample recording the highest and steamed OFSP the lowest. There was also a significant $(\mathrm{p}<0.05)$ increase in the protein content from $1.48 \%$ in the raw sample to $3.12 \%$ for roasted sample, $2.02 \%$ for micro waved sample and $1.83 \%$ for fried samples, while a decrease in protein content was observed for boiled (1.11\%) and steamed $(0.91 \%)$ OFSP respectively. Roasting improved the protein content of the OFSP by $52.5 \%$, microwave by $26.7 \%$ and frying by $19.1 \%$ while boiling reduced protein by $25 \%$ and steam by $38.5 \%$. The changes in the protein content of OFSP samples could also be attributed to leaching of nitrogen-containing compounds to the cooking medium (Saguy and Dana, 2003) as observed for boiled and steamed samples). The study showed that boiling is better than steaming in reducing protein loss. This may be because of higher latent heat of steam than boiling water, which leads to higher temperatures treatment and heat penetration during cooking, causing protein denaturation. (Richardson and Finley, 2000).

Crude fiber content ranged from $0.50-3.40 \%$ with the roasted OFSP sample recording the highest and microwaved OFSP sample lowest. Fiber content was found to increase for roasted sample (3.40\%), fried sample (3.2\%) and steamed OFSP (0.73\%), while a decrease was observed for boiled (0.53\%) and micro waved $90.50 \%)$ samples respectively. Thomas et al. (2017) reported an increase in the crude fiber content of roasted plantain (1.80-2.67\%) and fried plantain (4.54\%) respectively, while Robert et al. (2017) also reported the same increase for roasted yam $(0.17-0.20 \%)$, fried yam $(0.42 \%)$ and a decrease in crude fiber for boiled yam $(0.13 \%)$.

Carbohydrate content of the orange fleshed sweet potatoes ranged from $13.98-40.10 \%$ with roasted sample recording the highest and boiled OFSP sample the lowest. There was a significant $(\mathrm{p}<0.05)$ increase in the carbohydrate content from $19.75 \%$ in the raw sample to $40.10 \%$ for roasted sample, $26.17 \%$ for micro waved sample and $22.16 \%$ for fried samples, while a decrease in carbohydrate content was observed for boiled $13.98 \%$ and steamed $17.07 \%$ respectively. Gouadoet al.(2011) showed that there were losses in the carbohydrate content 
of sweet potato after boiling and frying. They deduced that these losses might be as a result of diffusion of free sugar from food to oil/water during frying and boiling.

Table 1.Proximate analysis of orange-fleshed sweet potato processed with different methods

\begin{tabular}{lllllll}
\hline Method & Moisture\% & Ash\% & Fat\% & Crude protein\% & Crude fiber\% & \% CHO \\
\hline Control & $75.95 \pm 3.89^{\mathrm{b}}$ & $0.63 \pm 0.17^{\mathrm{b}}$ & $1.49 \pm 0.33^{\mathrm{c}}$ & $1.48 \pm 0.24^{\mathrm{bc}}$ & $0.70 \pm 0.11^{\mathrm{cd}}$ & $19.75 \pm 3.05^{\mathrm{cd}}$ \\
Roasted & $49.25 \pm 2.05^{\mathrm{d}}$ & $0.99 \pm 0.16^{\mathrm{a}}$ & $3.15 \pm 0.10^{\mathrm{b}}$ & $3.12 \pm 0.74^{\mathrm{a}}$ & $3.40 \pm 0.01^{\mathrm{a}}$ & $40.10 \pm 1.37^{\mathrm{a}}$ \\
Fried & $66.45 \pm 0.49^{\mathrm{c}}$ & $0.32 \pm 0.04^{\mathrm{c}}$ & $6.01 \pm 0.06^{\mathrm{a}}$ & $1.83 \pm 0.07^{\mathrm{bc}}$ & $3.20 \pm 0.18^{\mathrm{b}}$ & $22.16 \pm 0.25^{\mathrm{c}}$ \\
Boiled & $83.10 \pm 0.57^{\mathrm{a}}$ & $0.32 \pm 0.12^{\mathrm{c}}$ & $0.97 \pm 0.01^{\mathrm{d}}$ & $1.11 \pm 0.04^{\mathrm{c}}$ & $0.53 \pm 0.02^{\mathrm{de}}$ & $13.98 \pm 0.65^{\mathrm{e}}$ \\
Micro waved & $69.05 \pm 0.21^{\mathrm{c}}$ & $0.85 \pm 0.04^{\mathrm{ab}}$ & $1.42 \pm 0.00^{\mathrm{c}}$ & $2.02 \pm 0.01^{\mathrm{b}}$ & $0.50 \pm 0.02^{\mathrm{e}}$ & $26.17 \pm 0.14^{\mathrm{b}}$ \\
Steamed & $79.65 \pm 1.06^{\mathrm{ab}}$ & $0.71 \pm 0.04^{\mathrm{b}}$ & $0.96 \pm 0.03^{\mathrm{d}}$ & $0.91 \pm 0.05^{\mathrm{c}}$ & $0.73 \pm 0.06^{\mathrm{c}}$ & $17.07 \pm 1.07^{\mathrm{de}}$ \\
LSD & 4.72 & 0.23 & 0.34 & 0.81 & 0.18 & 3.84 \\
\hline
\end{tabular}

Results are expressed as mean $\pm \mathrm{SD}, \mathrm{n}=2$. Values in the same column having different superscript are significantly different at $\mathrm{p}<0.05$.

\subsection{Mineral Composition ( $\mathrm{mg} / \mathrm{l} / 00 \mathrm{~g}$ ) of Orange Fleshed Sweet Potatoes as Affected by Processing Methods}

Table 2 shows the mineral composition of orange fleshed sweet potatoes as affected by processing methods. Zinc content of the orange fleshed sweet potatoes ranged from $5.22-6.22 \mathrm{mg} / 100 \mathrm{~g}$ with the boiled sample recording the highest and the roasted sample the lowest. Results showed that roasting reduced zinc content by $6.5 \%$, steam by $3.5 \%$ while the heat process by boiling increased zinc content by $11 \%$, frying by $1 \%$ and micro wave by $9.3 \%$. Zinc plays a key role in the regulation of insulin production by pancreatic tissues and glucose utilization by muscles and fat cells (Huang and Kirschke, 2016).

Copper content ranged from $2.08-4.16 \mathrm{mg} / 100 \mathrm{~g}$ with the control sample recording the lowest and the boiled sample the highest. There was an increase in the copper content of the orange fleshed sweet potatoes after processing from $2.08 \mathrm{mg} / 100 \mathrm{~g}$ in raw sample to $4.16 \mathrm{mg} / 100 \mathrm{~g}$ in boiled sample, $3.69 \mathrm{mg} / 100 \mathrm{~g}$ in micro waved sample, $3.40 \mathrm{mg} / 100 \mathrm{~g}$ in fried sample, $3.29 \mathrm{mg} / 100 \mathrm{~g}$ in roasted sample and $3.27 \mathrm{mg} / 100 \mathrm{~g}$ in steamed sample respectively. Boiled OFSP sample had an increased copper content significantly $(\mathrm{p}<0.05)$ different from all others.

Magnesium content ranged from 428.28-479.99mg/100g with control sample recording the lowest and boiled sample the highest. An increase in the magnesium content of the orange fleshed sweet potatoes was also observed for boiled sample with $479.99 \mathrm{mg} / 100 \mathrm{~g}$ and fried sample $475.49 \mathrm{mg} / 100 \mathrm{~g}$, roasted $473.84 \mathrm{mg} / 100$, micro waved $464.42 \mathrm{mg} / 100$ and steamed $438.24 \mathrm{mg} / 100$ respectively. There was a significant difference $(p<0.05)$ in the magnesium contents of the orange fleshed sweet potatoes treated with different processing methods. This is in agreement with the findings of Robert et al. (2017) who observed an increase in the magnesium content $(0.19-0.39 \mathrm{mg} / 100 \mathrm{~g})$ of boiled plantain.

Phosphorus content of the orange fleshed sweet potatoes ranged from $0.25-0.40 \mathrm{mg} / 100 \mathrm{~g}$ with the micro waved sample recording the highest and the control sample the lowest. There was an increase in the concentration of phosphorus from $0.25 \mathrm{mg} / 100 \mathrm{~g}$ in the raw sample to $0.42 \mathrm{mg} / 100 \mathrm{~g}$ in the steamed sample followed by micro waved sample with $0.40 \mathrm{mg} / 100 \mathrm{~g}$. Heat processing had no significant $(\mathrm{p}>0.05)$ effect on the potassium content of the orange fleshed sweet potatoes.

Potassium content reduced from $3288.24-2816.48 \mathrm{mg} / 100 \mathrm{~g}$ with the micro waved sample recorded the lowest and the control the highest. Frying and roasting methods had $4.15 \%$ loss in potassium, while micro waved processing incurred $16.75 \%$ loss in these minerals. The minimal loss in potassium in the roasted sweet potatoes could be due to increased concentration of minerals in the pulp through loss of water during the roasting process. A surface crust is readily formed around the food material during roasting, resulting in the sealing of the intracellular spaces. This could be the reason for the minimized losses that might have arisen as result of possible volatilization. Potassium is a vital mineral and electrolyte for the body. The adequate intake (AI) for potassium is $4,700 \mathrm{mg}$ in healthy individuals. Sweet potatoes therefore can be an alternative food to support its intake

Calcium content ranged from $177.92-280.50 \mathrm{mg} / 100 \mathrm{~g}$ with roasted orange flesh sweet potato sample recording the lowest and boiled OFSP the highest.Calcium content of the orange fleshed sweet potatoes was affected by boiling and steaming with concentrations of $280.50 \mathrm{mg} / 100 \mathrm{~g}$ and $210.00 \mathrm{mg} / 100 \mathrm{~g}$ respectively. While the other heat treatment employed (roasting, frying, and microwaving) caused a significant $(\mathrm{p}<0.05)$ decrease in the calcium content of the orange fleshed sweet potatoes. To support the findings of the present study, USDA(2009) reported that sweet potatoes are high in minerals such as potassium, calcium, magnesium, phosphorus, and iron. 
Table 2.Mineral composition $(\mathrm{mg} / 100 \mathrm{~g})$ of orange fleshed sweet potatoes as affected by processing methods

\begin{tabular}{lllllll}
\hline Samples & $\mathbf{Z n}$ & $\mathbf{C u}$ & $\mathbf{M g}$ & $\mathbf{P}$ & $\mathbf{K}$ & $\mathbf{C a}$ \\
\hline Control & $5.59^{\mathrm{d}}$ & $2.08^{\mathrm{f}}$ & $428.28^{\mathrm{f}}$ & $0.25^{\mathrm{f}}$ & $3,288.24^{\mathrm{b}}$ & $236.40^{\mathrm{b}}$ \\
Roasted & $5.22^{\mathrm{f}}$ & $3.29^{\mathrm{d}}$ & $473.84^{\mathrm{c}}$ & $0.28^{\mathrm{e}}$ & $3,157.20^{\mathrm{a}}$ & $177.92^{\mathrm{f}}$ \\
Fried & $5.65^{\mathrm{c}}$ & $3.40^{\mathrm{b}}$ & $475.49^{\mathrm{b}}$ & $0.34^{\mathrm{d}}$ & $3,157.20^{\mathrm{a}}$ & $187.84^{\mathrm{e}}$ \\
Boiled & $6.22^{\mathrm{a}}$ & $4.16^{\mathrm{a}}$ & $479.99^{\mathrm{a}}$ & $0.38^{\mathrm{c}}$ & $3,061.08^{\mathrm{c}}$ & $280.50^{\mathrm{a}}$ \\
Micro waved & $6.17^{\mathrm{b}}$ & $3.69^{\mathrm{c}}$ & $464.42^{\mathrm{d}}$ & $0.40^{\mathrm{a}}$ & $2,816.48^{\mathrm{e}}$ & $178.70^{\mathrm{d}}$ \\
Steamed & $5.40^{\mathrm{e}}$ & $3.27^{\mathrm{e}}$ & $438.24^{\mathrm{e}}$ & $0.42^{\mathrm{b}}$ & $2,951.04^{\mathrm{d}}$ & $210.00^{\mathrm{c}}$ \\
\hline
\end{tabular}

Results are expressed as mean $\pm \mathrm{SD}, \mathrm{n}=2$. Values in the same column having different superscript are significantly different at $\mathrm{p}<0.05$

\subsection{Total Carotenoid and Vitamin C Content of Orange-Fleshed Sweet Potatoes (OFSP) Processed with Different Methods}

Figure 2 shows the total carotenoid and vitamin C content of OFSP processed from different methods. Total carotenoid ranged from $2.59-5.29 \mathrm{mg} / \mathrm{g}$ with control sample recording the highest and fried OFSP sample as the lowest. Carotenoid losses were higher after frying $2.59 \mathrm{mg} / \mathrm{g}$, steaming $2.68 \mathrm{mg} / \mathrm{g}$, micro waved $3.91 \mathrm{mg} / \mathrm{g}$, boiling $4.60 \mathrm{mg} / \mathrm{gand}$ roasting $4.73 \mathrm{mg} / \mathrm{g}$ respectively. It is known that longer cooking time can increase the extractability and probably improve the bioavailability of carotenoid content from the vegetable matrix. According to Mayer-Miebach et al., (2005), the presence of oil increases the trans-cis isomerization during a short time treatment of foods. Thus, extensive losses during frying of the orange fleshed sweet potatoes may be probably due to the presence of oil.

Vitamin C content of the OFSP samples ranged from $0.01-0.20 \mathrm{mg} / 100 \mathrm{~g}$ with the steamed sample recording the highest and roasted sample the lowest. The result showed that processing method affected the Vitamin $\mathrm{C}$ content of the samples. Solubility and leaching may be the main reasons for the high loss of ascorbic acid during cooking. Different studies havefound a decrease of ascorbic acid by boiling up to75\% (Gould and Golledge, 1989; Pattersen, 1998; Schnepf and Driskell, 1994).Some authors reported about losses of $3.7 \%$ by boiling different vegetables while others have found increases of $18 \%$ by pressure steaming(Booth and Bradford, 1963; Brubacher, 1966).Steaming method was found to increase the vitamin $C$ content of the orange fleshed sweet potatoes from $0.08-0.20 \mathrm{mg} / 100 \mathrm{~g}$ while losses were more for roasting method with $0.01 \mathrm{mg} / 100 \mathrm{~g}$. Loss as a result of boiling is justified since vitamin C is water-soluble and heat labile (Egerget al., 1977). Thus vitamin C is easily leached into the boiling medium.

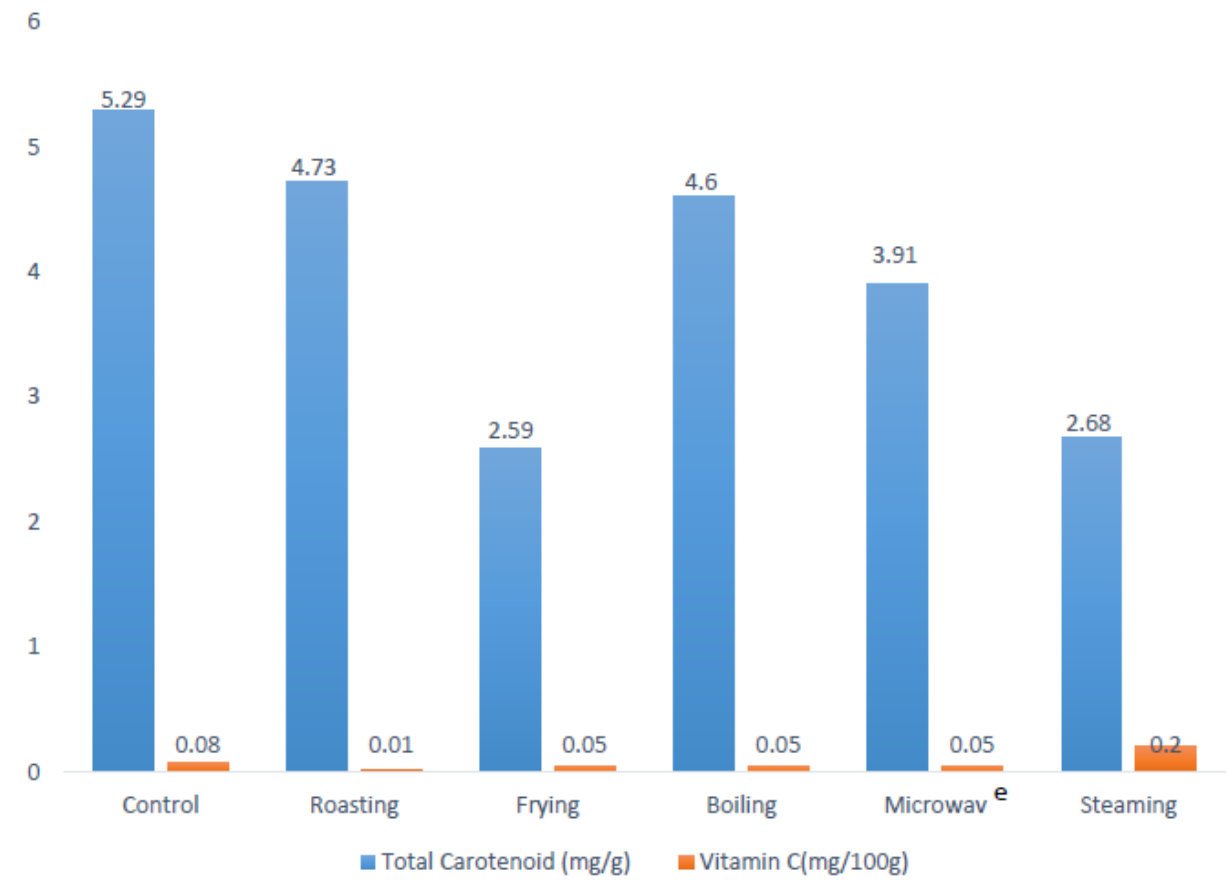

Figure 2. Carotenoid and Vitamin C content of Orange-fleshed sweet potato as affected by processing method 


\subsection{Sensory Analysis of Orange-Fleshed Sweet Potatoes (OFSP) Processed with Different Methods}

The results of the sensory evaluation of orange fleshed sweet potatoes processed with different heat treatment method is shown in Table 3.

The mean sensory scores for the orange-fleshed sweet potato samples showed that fried, boiled, micro waved and roasted orange fleshed sweet potatoes were highly acceptable by the panelists

Color ranged from 5.10-6.35 with roasted sample as least preferred and steamed sample as most preferred. Results show that the roasted sample was significantly $(\mathrm{p}<0.05)$ different from all others. Roasting had an effect on the color of the OFSP due to crust that was formed on the roasted potato.

Taste of the OFSP samples ranged from 4.70-5.75 with the boiled sample having the least value and fried sample as most preferred.

Mouth feel of the processed OFSP ranged from 3.95-4.10 with the boiled sample as the least and micro waved and steamed samples as the highest, while texture ranged from 4.75-5.55 with the fried sample as the most preferred.

Overall acceptability of the OFSP ranged from 5.15-6.15 with steamed having the least and roasted sample as most preferred. Samples with different cooking methods showed no significant $(\mathrm{p}>0.05)$ difference in taste, mouth feel, texture and overall acceptability from each other.

Table 3. Sensory analysis of orange-fleshed sweet potatoes processed with different methods

\begin{tabular}{llllll}
\hline Methods & Color & Taste & Mouth feel & Texture & OverallAcceptability \\
\hline Fried & $6.20^{\mathrm{a}}$ & $5.75^{\mathrm{a}}$ & $5.00^{\mathrm{a}}$ & $5.55^{\mathrm{a}}$ & $5.90^{\mathrm{a}}$ \\
Boiled & $6.10^{\mathrm{a}}$ & $4.70^{\mathrm{a}}$ & $3.95^{\mathrm{a}}$ & $4.95^{\mathrm{a}}$ & $5.50^{\mathrm{a}}$ \\
Roasted & $5.10^{\mathrm{b}}$ & $5.95^{\mathrm{a}}$ & $5.30^{\mathrm{a}}$ & $5.20^{\mathrm{a}}$ & $6.15^{\mathrm{a}}$ \\
Micro waved & $5.45^{\mathrm{a}}$ & $5.35^{\mathrm{a}}$ & $4.10^{\mathrm{b}}$ & $4.75^{\mathrm{a}}$ & $5.20^{\mathrm{a}}$ \\
Steamed & $6.35^{\mathrm{a}}$ & $4.85^{\mathrm{a}}$ & $4.10^{\mathrm{a}}$ & $4.75^{\mathrm{a}}$ & $5.15^{\mathrm{a}}$ \\
LSD & 3.02 & 3.07 & 3.02 & 2.79 & 2.54 \\
\hline
\end{tabular}

Values in the same column having different superscript are significantly different at $p<0.05$

\section{Conclusion}

This study has shown that processing methods has a significant effect on the proximate, mineral and sensory properties as well as in vitamin $\mathrm{C}$ and total carotenoid content of Orange-fleshed sweet potatoes. Roasting enhanced the ash, protein, crude fibre and carbohydrate content of the orange-fleshed sweet potato more than other processing treatment while fat content was increased when the OFSP were fried. Vitamin C losses were observed for roasted and steamed samples while this was minimal for fried, boiled and micro waved OFSP samples. At the same time, Carotenoid losses were observed in all methods with roasting having the least loss. The study also revealed that boiling of orange-fleshed sweet potatoes resulted to an enhancement in the minerals such as zinc, copper, magnesium and calcium contents, while sensory analyses gave acceptable products with the various methods.

\section{References}

AOAC.(2012). Official methods of Analysis, Washington D.C,USA.Association of Official Analytical Chemists.

Booth, V. H., \& Bradford, M. P. (1963).The effect of cooking on a-tocopherol in vegetables.International Journal of Vitamin Research, 33, 276-277.

Brubacher, G. (1966). Uber den Vitamin E-GehalteinigerNahrung-smittel.InternationaleZeitschrift fur Vitaminforschung, 38, 409-415

Chukwu, O, Orhevba, B.A., \&Mahmood, B.A. (2010).Influence of Hydrothermal Treatments on Proximate Compositions of Fermented Locust Bean (Dawadawa).Journal of Food Technology, 8(3), 99-101. https://doi.org/10.3923/jftech.2010.99.101

Degras L (2003). Sweet Potato. Macmillan, Oxford. England.

Egerg, K., Arson, A., \&Etok, F (1977).Semi-Automated Method for the Fluorometric Determination of Total Vitamin C in food product.Journal Association Analytical Chemist, 60(1), 126-131

Erdman, J.W., \& Schneider, A.G. (1994). Factors affecting nutritive value in processed food. Romanian Journal Food Science, 12, 111-136. 
Food and Africultural Organization, FAO (2007).Root and Tuber Crops, Plantains and Bananas in Developing Countries: Challenges and Opportunities. Rome, Italy; Food and Agriculture Organization of the United Nations.

Genah, D.I., Eke, M.O., \&Ariahu, C.C. (2012). Chemistry and sensory evaluation of bread sold in benue and nasarawa states on central Nigeria. Advanced Journal of food Science and Technology, 5, 547-550.

Gouado, I., Demasse, M. A., Etame, L. G., Meyimgo, O. R. S., Ejoh, A. R., \&Fokou, E. (2011). Impact of Three Cooking Methods (Steaming. Roasting on Charcoal and Frying) on $\beta$ - carotene andvitamine $\mathrm{C}$ content of plantain and sweet potatoes. American Journal of Food Technology, 6, 994-1001. https://doi.org/10.3923/ajft.2011.994.1001

Gould, M. F., \&Golledge, D. (1989). Ascorbic acid levels in conventionally cooked versus microwave oven cooked frozen. Food Sciences and Nutrition, 42, 145-152.https://doi.org/10.1080/09543465.1989.11904139

Harborne, J.B. (1973). Phytochemical Methods.Chapman and Hall Ltd., London, UK. pp. 49-188.

Huang, L., \&Kirschke, C.P. (2016): Down-regulation of zinc transporter 8 (SLC30A8) in pancreatic beta-cells promoes cell survival. Austin Journal Endocrinol Diabetes, 3(1), 1037.

Iheokoronye, A., \&Ngoddy, P. (1985).Integrated Food Science and Technology for the Tropics.McMillan pub.Ltd. London.

Johu, W. (1998).Tropical crops: Dicotyledons. An untapped Food Resource. Longman scientific and Technical, New York, USA; John Williams and sons, Inc.

Larmond, E. (1991). Laboratory Methods for Sensory Evaluation of Foods.CanadianAgricultural Publications.Series IV, Ottawa. Canada

Mayer-Miebach, E.,Behsnilian, D.,Regier, M.,\&Schuchmann, H. P. (2005). Thermal processing of carrots: Lycopene stability and isomerisation with regard to antioxidant potential. Food Resources International, 38, 1103-1108.https://doi.org/10.1016/j.foodres.2005.03.018

Onwuka, G.I. (2005). Food analysis and instrumentation theory and practice. Lagos, Nigeria. Naphati prints.

Patterson, D.R. (1998).True Roots, Sweet potatoes.Taxas AG Progress, Winter 1979J. Agric2345; 56789, 7655445 .

Richardson, T., \& Finley, J.W. (2000).Chemical changes in Food during processing. New Delhi: CBS Pvt. Ltd.

Robert, A., Elsie, S.A., \&Hayford, D. (2017).Effect of Cooking Methods and Ripening Stages on the Nutritional Compositions of Plantain (Musa Paradisiaca).International Journal of Food Science and Biotechnology, 2(4), 134-140.

Rodriguez-Amaya, D.B., \& Kimura, M. (2004).Harvest plus Handbook for Carotenoid Analysis.Harvest plus Technical Monograph 2.IFPRI, Washington D.C.

Saguy, I. S., \& Dana, D. (2003). Integrated approach to deep fat frying: Engineering, nutrition, health and consumer aspects. Journal Food Engineering,56, 143-152.https://doi.org/10.1016/S0260-8774(02)00243-1

Schnepf, M., \&Driskell, J. (1994). Sensory attributes and nutrient retention in selected vegetables prepared by conventional and microwave methods. Journal of Food Quality, 17, 87-99. https://doi.org/10.1111/j.1745-4557.1994.tb00135.x

Thomas, O.A., Boyejo, O., \&Adeniji, O.P (2017).Nutrient and antinutrient composition of yellow yam (Dioscoreacayenensis) products.DATA in brief, 11, 428-431.

Tsado, A.N., Lawal, B., Santali, E.S., Shaba, A.M., Chirama, D.N., Balarabe, M.M., Jiya, A.G., \& Alkali, H.A (2015). Effect of Different Processing Methods.Journal of Nutritional Composition of Bitter Leaf (vernoniaamygdalina), 5(6), 08-14

USDA (U.S. Department of Agriculture), Agricultural Research Service. (2009). USDA National Nutrient Database for Standard Reference, Release 22. Nutrient Data Laboratory Home.Retrieved from http://www.ars.usda.gov/ba/bhnrc/ndl, Accessed 14 September 2012.

Woolfe, A.J., \&Jennifer, A. (1992).Sweet potato; An untapped food Resourse, Cambrige ,UK; Cambridge University press and the international potato center(CIP).

Woolfe, A.J. (2008). Sweet Potato: An Untapped Food Resource, 2nd ed.; Cambridge University Press: New York, NY,USA. 


\section{Copyrights}

Copyright for this articleis retained by the author(s), with first publication rights granted to the journal.

This is an open-access article distributed under the terms and conditions of the Creative Commons Attribution license (http://creativecommons.org/licenses/by/4.0/). 